\title{
Venter's departure sees Celera seek therapies
}

Carina Dennis

The announcement on 22 January that Craig Venter was stepping down as president of Celera provided few clear pointers about the future of either the maverick geneticist or the biotechnology operation, based in Rockville, Maryland. But according to observers of both, the man may have a better chance of landing on his feet than the company he built.

Celera's revenues are projected to reach $\$ 130$ million this year, as more academic and commercial users subscribe to its genome databases. That will make the company profitable, but it won't meet investors' heady expectations. So, for the past year or so, Celera has been pursuing a new business plan based on drug discovery.

But Tony White, chief executive of Celera's parent company, Applera, and now acting president of Celera itself, acknowledges the company's lack of expertise in drug discovery. He says there will now be a "top-to-bottom review" of the company's operations, and that it will hire the skills it will need. In this endeavour, Celera's greatest asset may be its cash reserve of almost $\$ 1$ billion, accrued when investors' hopes for the company peaked two years ago.

Venter's departure leaves the door open for White to recruit a new leader for Celera with the right experience in drug discovery and development. The company has reorganized to focus on the systematic identification of proteins that are expressed differently in diseased tissue and normal tissue, and which may represent good drug targets.

But lists of poorly characterized potential drug targets have little value in themselves. In November, Celera bought Axys Pharmaceuticals, a small-molecule drug development company based in San Francisco, whose capabilities in pharmacology, assay development and structural biology will help it to select the most promising drug targets.

Samuel Broder, Celera's chief medical officer, says this results in a "unique combination of proteomics, combinatorial chemistry and computational biology" that will give Celera an edge in drug discovery. The company says it has already identified a couple of promising compounds for the possible treatment of autoimmune disease and thrombosis.

But sceptics point out that neither Celera nor Axys has an established track record in this area. "Celera is one of perhaps 500 to 1,000 raw start-up companies interested in drug discovery that is in a rudimentary and undefined state," says William Haseltine, a former colleague and long-time critic of Venter. Haseltine is chief executive of Human Genome Sciences, another Rockville-based

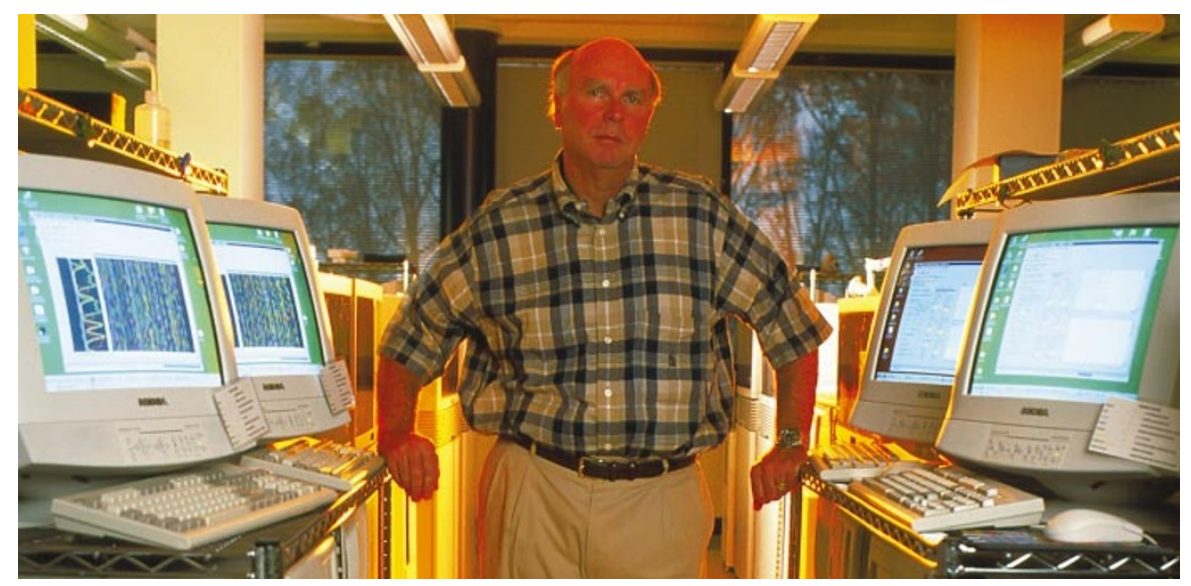

On the hunt: Craig Venter leaves Celera competing with many companies in the search for new drugs.

biotechnology company. He adds that any small company "that thinks it can outdo large companies in chemical-based drug discovery" is labouring under a major misconception.

Venter's departure was not entirely unexpected, and had little impact on Celera's stock. It held steady at a value of around $\$ 23$ during the week of the announcement — far below its March 2000 high-water mark of $\$ 247$.

Celera's sister company, Applied Biosystems, has suffered from declining sales of its sequencing machines and reagents, which it attributes mainly to lower-than-expected demand from genomics researchers.

As for Venter himself, the normally voluble bête noire of US molecular biology was unavailable for comment, reportedly sunning himself on his racing yacht in the Caribbean.

According to Broder, Venter is "returning to his first love: science". There's no word yet on when or where Venter will resurface, but as Broder puts it: "There are always creative surprises whenever Craig is involved.”

\section{Senators square up over cloning}

Erika Check, Washington

With the US Senate set to debate legislation on human cloning over the next few weeks, senators are lining up behind two rival positions on the issue.

On 24 January, senators Tom Harkin (Democrat, Iowa) and Arlen Specter (Republican, Pennsylvania) introduced a bill that would allow cloning of human embryos for research purposes, but ban its use in human reproduction.

This legislation is similar to a bill introduced last month by Dianne Feinstein (Democrat, California). For jurisdictional

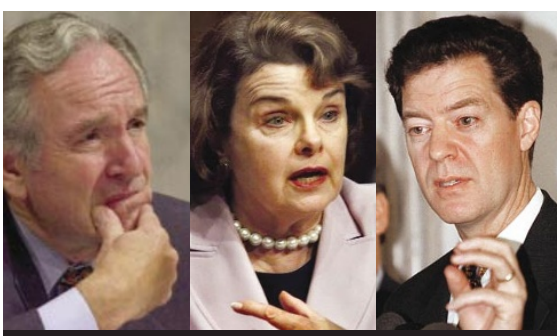

Putting proposals: (from left to right) Tom Harkin, Dianne Feinstein and Sam Brownback. reasons, Feinstein's bill is more likely to make it to the Senate floor, where it will compete with a proposal from Sam

Brownback (Republican, Kansas) that would ban cloning for any purpose.

Most research organizations, including the Federation of American Societies for Experimental Biology and the Association of American Medical Colleges, have backed the Feinstein bill.

The Senate has yet to take a vote on the politically charged issue of cloning, although Senate majority leader Tom Daschle

(Democrat, South Dakota) has responded to increasing pressure to do so by promising to allow time for a debate during February or March. The House of Representatives passed a ban on cloning for research or reproduction last July by a margin of 265 to 162 .

But Congress may still fail to agree on legislation. The Senate is thought to be closely divided on the issue, but if it passes the Feinstein bill, it is highly unlikely that House and Senate negotiators would be able to agree a compromise on the basic issue of whether cloning should be permitted for research purposes. 